No There There 
The publisher gratefully acknowledges the generous contribution to this book provided by the General Endowment Fund of the University of California Press Associates. 


\title{
No There There
}

Race, Class, and Political Community in Oakland

\author{
CHRIS RHOMBERG
}

University of California Press

BERKELEY LOS ANGELES LONDON 
This book was published with the assistance of the Frederick W. Hilles Publication Fund at the Whitney Humanities Center, Yale University.

University of California Press

Berkeley and Los Angeles, California

University of California Press, Ltd.

London, England

(C) 2004 by the Regents of the University of California

Library of Congress Cataloging-in-Publication Data

Rhomberg, Chris, 1959-

No there there : race, class, and political community in Oakland / Chris Rhomberg.

p. $\mathrm{cm}$.

Includes bibliographical references and index.

ISBN 0-520-23618-1 (alk. paper)

1. Oakland (Calif.) —-Race relations. 2. Oakland (Calif.)—Politics and government-2oth century. 3. Oakland (Calif.)—Social conditions-2oth century. 4. African Americans-Civil rightsCalifornia-Oakland-History—2oth century. 5. Black powerCalifornia-Oakland-History-2oth century. 6. Social classesCalifornia-Oakland-History-2oth century. 7. General strikesCalifornia-Oakland-History-2oth century. 8. Ku Klux Klan (1915-)-California-Oakland-History-2oth century. 9. Social conflict-California-Oakland-History—2oth century. I. Title. $\mathrm{F}_{669 .} \mathrm{O}_{2} \mathrm{R}_{4} 8 \quad 2004$ $979.4^{\prime} 6605-\mathrm{dc} 21$ 2003000598

Manufactured in the United States of America

$\begin{array}{llllllllll}13 & 12 & 11 & 10 & 09 & 08 & 07 & 06 & 05 & 04\end{array}$

$\begin{array}{llllllllll}10 & 9 & 8 & 7 & 6 & 5 & 4 & 3 & 2 & 1\end{array}$

The paper used in this publication meets the minimum requirements of ANSI/NISO Z39.48-1992 (R 1997) (Permanence of Paper).@ 